\title{
Mr Theodore Mundstock (Pan Theodor Mundstock)
}

Author: Ladislav Fuks

First Published: 1963

Translations: German (Herr Theodor Mundstock, 1964); Hungarian (Mundstock úr, 1965); Spanish (El Señor Theodor Mundstock, 1965); English (Mr Theodore Mundstock, 1968); Romanian (Domnul Theodor Mundstock, 1973); Bulgarian (Gospodin Teodor Mundštok, 1986); Nederland (Meneer Theodor Mundstock, 1986); Croatian (Gospodin Theodor Mundstock, 1988); Slovak (Pân Theodor Mundstock, 1988); Italian (Il signor Theodor Mundstock, 1997); French (Monsieur Mundstock, 2004).

Theatre Adaptations: Činoherní studio, Ústí nad Labem (1984, adaptation and director Jaroslav Achab Haidler); Théâtre de l'Eldorado de Lyon (1993, adaptation and director Bruno Boëglin); New York, Theater for the New City and JCC Manhattan (adaptation and director Vit Hořejš, Czechoslovak-American Marionette Theater, under the title $M r . M$; 2011); Divadlo hrdinů, Prague (adaptation and director Miloš Horanský, 2016).

Film Adaptation: Kartka z podróży (A Postcard from the Journey), feature film, screenplay Waldemar Dziki; film director Waldemar Dziki, premiered 1984.

Comics: Nikola Logosová: Pan Theodor Mundstock. Prague 2012.

About the Author: Ladislav Fuks (1923-1994) was born in Prague as the son of a high ranking police officer. In high school, he witnessed the Nazi persecution of his Jewish friends. In 1942 he was forced to work on a farm in Moravia. After World War II, he studied philosophy, psychology and art history at Charles University in Prague. He became a professional writer in the 1960s, after his successful debut of $\mathrm{Mr}$ Theodore Mundstock. Jewish figures and the Holocaust play an important role in his works from the 1960s.

Further Important Publications: Variace pro temnou strunu (1966, Variations on a Dark Chord; novel); Spalovač mrtvol (1967, $\rightarrow$ The Cremator; novel); Smrt morčete (1969, Death of the Guinea Pig; short stories).

\section{Content and Interpretation}

The novel, divided in 21 chapters, is set in Nazi-occupied Prague (1941-1942). Its protagonist is a shabby man about fifty, a Jew named Theodore Mundstock, a former accountant. Now he is forced to work as a street sweeper. He awaits his summons for the transport to a concentration camp. Like many other Fuks's characters, Mund- 
stock exists in a world that bears much fear and he does not recognise the boundary between reality and imagination. He creates his own ideas of time and space. He lives alone except for a pet pigeon and his own "shadow" and doppelgänger Mon whom he talks to. Mundstock doesn't think of any active resistance to the occupier; he follows all German anti-Jewish orders. He comforts his friends, the Stern family, but he realises the hopelessness of his situation. He tries to commit suicide, however, is saved by his neighbour Čižek, a communist, and the pigeon at the cost its own life. Later Mundstock visits a rabbi and seeks for advice. The old rabbi tells him, that the Jews must accept suffering as part of the deal for the chosen nation.

After few days, Mundstock is reminded of Rabbi Yehuda bar Elai's words, that the Jews are likened to the dust and likened to the stars. Mundstock who as usual was sweeping the dirty street, still felt the dust. Now he "felt himself begin to rise to the stars" (Fuks, 1968, p. 104). It is the breaking point for him. He is convinced to find his "road to salvation", and thus he creates a "method" of overcoming. He tries to find his hope by thinking out and perfecting strategies for endurance and surviving the transport and camps. At this moment, his shadow Mon disappears. Mundstock prepares for things that are very different from his usual existence. For instance, for getting into a convoy, training for hunger and starvation, heavy work in a quarry, uncomfortable sleeping (he practises by using an ironing board as a bed), for beeing shouted and beaten by Nazis, and by losing his teeth so that the soldier will feel that the beating has produced a good result. He even practices his own death, by shooting or in a gas chamber.

Further transports go on, and Mundstock's former girlfriend Ruth Kraus as well as the Stern family (except little Simon) must leave. Mundstock takes care of Simon and teaches him about his method. At last, Mundstock and Simon are both also summoned for transport. On the way, Mundstock keeps his prepared strategy. He stops and changes his little suitcase from one hand to the other. He spots Simon on the platform and calls his name. But then Mundstock is knocked down and killed by a German lorry. Mundstock knows that life has a very unpredictable nature. At that moment, Simon comes to him and merges with Mon. Pictures of "dust" and a "star" appear again: "The yellow Jewish star on his dark blue coat was covered in dust, but strange to say there was not a speck of blood on it” (p. 214).

\section{Main Topics and Problems}

In $\mathrm{Mr}$ Theodore Mundstock the author tries to depict the tragic, absurd situation of the Jews during the Holocaust, and at the same time to give a picture of the plight of man in general. The main character is a Jew who, through no fault of his own, finds himself under extreme threat and is trying to defend himself. Ironically, in the end he is killed in a traffic accident; he dies as a victim of the Shoah. Nevertheless, the novel also reproduces the destruction of human rights (not as arbitrary violence, but as a regular system), an atmosphere of mutual and accepted deception, where the truth is a taboo. 
The novel contains many details from Jewish cultural and religious life. For instance, Jewish feasts (Pesach, Shavuot, Hanukkah, Rosh Chodesh) and biblical figures (Rebecca, Judith). Mundstock sings Hanukkah's prayer in Hebrew and the rabbi quotes an Early Medieval Jewish scholar, Judah Halevi.

Fuks' novel is in many aspects similar to Jiři Weil's $\rightarrow$ Life with a Star (1949), in part also Ladislav Grosman's $\rightarrow$ The Shop of Main Street (1965). All of them blend tragedy and the grotesque. Also Weil's Roubíček as well as Grosman's Brtko are little men, non-heroes, almost comic figures. Nevertheless, while Tono Brtko is a Slovak, Josef Roubíček is a Jew waiting alone in the suburbs of Prague to be taken to a concentration camp. Also he has a former girlfriend, and now a pet cat, whom he talks to. Also neither Nazi brutality nor heroic resistance are mentioned in Weil's book. Both characters are concerned with trivial everyday things. The horror and even the absurdity of the situations depicted come from the "usual" way of Nazi totalitarianism, from the acceptance of the degradation of human relationships as a matter of course - in some respects, the stories are told in a very Kafkaesque manner. However, the ends are very different: Roubíček decides not to go into the transport and to move to a hiding place, with the help of Czech labourers, while Mundstock dies on the way to the transport gathering place.

Unlike Life with a Star, the story of Mundstock is told in the third person narration. But almost everything is seen - as well as in Fuks' $\rightarrow$ The Cremator - through the eyes of the main character. Both characters, Mundstock and Kopfrkingl are disturbed. Similar to Mundstock, Kopfrkingl believes that phantoms and mirages do, in truth, exist. In Mundstock's internal world his imagined doppelgänger, Mon, becomes a reality; Kopfrkingl thinks, a Tibetan monk visits him. However, Mundstock is an outsider and introverted character, Kopfrkingl turns into an aggressor and a murderer.

Like other of Fuks' novels and short stories, the novel Mr Theodore Mundstock is based on stylisation and complicated construction. The entire text is full of allusions and symbols; a network of anticipations and hints is created. So the death of Mundstock is anticipated in the third chapter:

As he crossed the road he almost got in the way of a truck. For a split second people on the pavement stiffened, but the driver went on... (p. 30)

[...] "was it so bad going along the street, after all?"

"Well, I wouldn't want to get run over", he said, "but I’ve got eyes in my head”. (p. 36)

The words "dust" and "star" (see above) play an important role. Both of them have several meanings, direct as well as transmitted and religious. Mundstock has a lamp in his room. There is a picture of Columbus's ship on the lampshade. In the first half of the story, this boat stays in place. After Mundstock had invented his "method", "the ship [...] sailed out of the darkness and began to move” (p. 132). It suggests hope. Later, in the chapter 20, Columbus's ship sailed calmly nearer to its goal. Mundstock thinks that this goal is his rescue. But it turns out that it is his death. Mundstock invents his method on a Friday and a Friday is also the day when he dies. He believes he 
can be chosen. I could be a hint to Jesus Christ and his death on a Friday. Also the names Mon and therefore Simon are symbolic.

Mr Theodore Mundstock was the first edited book of Ladislav Fuks. It became wellknown and was translated into many languages. It was also supposed to be filmed; at first by Charlie Chaplin, and later Roman Polanski considered working on the adaptation, however, refused perhaps due to Fuks’ particular nature (Poláček, 2013, pp. 140142). The adaptation was not made until 1984 when the Polish director Waldemar Dziki created the film version of Mundstock under the title A Postcard from the Journey. It was situated in a ghetto in Poland and characters were Polish Jews.

\section{Cited Works}

Fuks, L. (1969). Mr Theodore Mundstock. London: Grossman Publishers. Poláček, J. (2013). Př́běh spalovače mrtvol. Dvojportrét Ladislava Fukse. Praha: Plus.

\section{Further References}

Bauer, M. (2001). Příprava vydání románu Pan Theodor Mundstock od Ladislava Fukse. Tvar, 12(20), pp. 14-15 and (21), pp. 14-15. Elman, R. M. (1968). Anatomy of Terror. New York Times, 28. 1., p. 96. Kanikova, S. I. (1989). The Jews in the Works of Ladislav Fuks. In: Y. Bauer et al., eds., Remembering for the Future, vol. 3, The Impact of the Holocaust and Genocide on Jews and Christians. Oxford: Pergamon, pp. 2946-2957. Klima, C. A. (2002). Mr Theodore Mundstock (Pan Theodor Mundstock). In: T. Riggs, ed., Reference Guide to Holocaust Literature. Detroit: St James Press, pp. 512-513. Pynsent, R. B. (2004). Ladislav Fuks. In: E. Sicher, ed., Holocaust Novelists. Detroit: The Gale Group, pp. 47-59. Schott, W. (1968). Minor Miracle of a Czech Everyman. Life, 26. 1., p. 8. Vlašínová, D. (2000). Pohledy na českou literaturu dvou století. Opava: Slezská univerzita, pp. 127-138. Winner, T. (1970-1972). Some Remarks on the Art of Ladislav Fuks. Revista storica italiana, 17-19, pp. 587-599. 